\title{
ARCTIC DRAMA TO SÁMI THEATRE - CULTURAL CLASHES TOWARDS DECOLONISATION: IN SHARED DIALOGIC SPACES
}

\begin{abstract}
Summary. This article deals with the concept of Arctic Drama, which is about how there is a relationship between drama and cultural clashes in the perspective of shared cultures in the northern Scandinavian area, which is defined as arctic in the geographical sense. In this vast area the Sámi people historically and to the present day have been living from reindeer herding in a nomadic lifestyle, giving them a close relationship to nature.

Norwegians and Swedes colonised this area historically, especially the coast for fishing. There have been strong cultural clashes since the Viking ages, but colonisation mainly started later by introducing Christianity by force in the $16^{\text {th }}$ century. Since the Romantic age, these ethno-cultural clashes have been reflected in drama and theatre, and some plays by Henrik Ibsen and Knut Hamsun echo these tensions. An independent theatre of the Sámi people as well as of other indigenous people in Greenland and Canada, like the Inuits, would also develop some theatrical strategies based in a dramaturgy that could be described as a "spiral dramaturgy". Cultural independence has contributed to a decolonisation process, contributing to even out the cultural clashes in theatre and drama, which could be defined as postcolonial towards decolonisation. This article focuses on the area of arctic Scandinavia.
\end{abstract}

Keywords: Arctic Drama, Sámi and indigenous people, dialogic spaces, shared culture, centre and periphery.

\section{INTRODUCTION}

An interest in postcolonial positions and decolonisation has arisen again in theatre and drama studies. Cultural clashes of values and ecology in-between indigenous societies and dominant more powerful societies ("storsamfunn"), can also be seen in this perspective. This interest can also be applied to Arctic Scandinavia with regard to the Sámi people as well as to Inuit societies in Greenland and Canada. In all these cases one can speak about decolonisation in the sense of overcoming ethno-cultural tensions, which is my way of using the term decolonisation which presupposes cross cultural communication. In this sense, there is an interaction in-between people who are neighbouring each other in the Arctic. This is mostly the case in Northern Scandinavia, where traditionally and historically coastal areas and to some extent the tundra has been a shared area. Therefore, this way there is not a postcolonial situation with a coloniser withdrawing by the process of decolonisation. Instead of that, dialogic spaces is the term I will apply to this situation. In my perspective, artistic development is an essential part of this decolonisation process. So, in this study dialogic space is a concept describing artistic creation and communications between partners in an exchange situation reflecting the spiritual, the vernacular, and the political. This is often the case in borderland exchanges ${ }^{1}$ and decolonialisation can be seen as state of reconciliation between centres and peripheries. ${ }^{2}$ Northern Scandinavia and the arctic is a borderland between the mainstream Scandinavian societies and indigenous people of the North, like the Sámi and the Inuits in Greenland and Canada, as well as in Russia and Alaska. This is too vast an area to cover in one study, but in my point of view dialogic spaces are paving the way to speak about cultural clashes as shared culture in most of these areas of predominantly arctic climate.

\section{CULTURAL CLASHES AND ARCTIC DRAMA}

This article focuses on Arctic Drama and Sámi Theatre in a centre to periphery context, reflecting an understanding of a shared Arctic drama. 
Historically, cultural clashes of the colonial times in $19^{\text {th }}$ and early $20^{\text {th }}$ centuries, are to my mind a backdrop to the situation of Sámi Theatre blossoming in the 1970s and 1980s and since. This change was first due to postcolonial needs to create new identities, and then a result of shared culture as a premiss for decolonisation. This process has been spurred by the struggle of protecting natural environments and craving political rights, which led to a creation of cultural identity to replace the colonial gaze. The Arctic can be defined both climatically, culturally and geopolitically, and it is a fascinating example of spectacular nature and vernacular culture. In books like Arnold Weinstein's Northern Arts, ${ }^{3}$ and Peter Fjågesund's The Dream of the North, ${ }^{4}$ we find attempts at describing cultural history and geographical discovery from different times and borderlines. How come that the Nordic and the Arctic became so closely related through by the way the Romantic movement and Modernism kept a close look at nature in the sense of landscapes and the sky, expressed in Symbolism and Impressionism? This can more or less be seen as exemplified in Ibsen, Munch, Sibelius and Strindberg. One explanation is found in the fact that the relation between landscapes and culture was strongly represented in theatre, painting and literature, in direction of a comprehension of art that broke with the logics and hierarchies of the classicistic norms of symmetric forms. This can also be seen in connection to cultural clashes as spurred by the clashes between Sámi people and the dominance of the colonising kingdoms of Sweden, Denmark and Norway. Arctic Drama can of course also be seen as hardships in the lives of people living in the polar areas, and can thus be defined as the experience of excitement connected to polar expeditions, hunting tours or mountain climbing which also found its expression in local, vernacular drama and amateur theatre. It could also, in both drama and visual art, be created in artworks by visitors being impressed and taken by the landscape. This will also relate to professional artistic examples of artworks dealing with arctic landscape as well as cultural and memory clashes in scenic polar context. The term Arctic Drama was first internationally launched at the conference of the International Association of Scandinavian Studies (IASS) in Gdansk, Poland, in 2008. The title of the conference was Nordic Drama: Renewal and Transgression, and it would display a challenge in searching for - and describing - dramaturgic models in the range between epical techniques of drama, shamanism, storytelling and Ulla Ryum's circular and spiral dramaturgy, ${ }^{5}$ which was applied by David Schuler to understand the Sámi chanting form, the joik. To exemplify, Schuler uses Finnish-Sámi artist and playwright Nils-Aslak Valkepääs plays, The FrostHaired and The Dream Seer, as examples of Sámi drama built up around the narrative structure of the joik, the way of guttural singing that creates portraits of landscapes and people without any given narrative. Schuler shows how, with reference to Ryum's suggestion that the joik is connected to a spiral or circular dramaturgy based in a storytelling reflecting the portraits of persons and nature in the joik, ${ }^{6}$ 104-105.7 Knut Brynhildsvold was contributing on Knut Hamsun's authorship and dramas, like in relation to the theatricality of his novel Hunger. ${ }^{8}$

\section{ZOGBAUM TO IBSEN AND HAMSUN}

Cultural clashes among ethnic groups can be traced in the plays by Henrik Ibsen and Knut Hamsun. But there is one forerunner who is little known, a woman by the name of Emilia Zogbaum, a schoolteacher living some years in the mid $19^{\text {th }}$ century, in the northernmost city of the world, Hammerfest. Hans Lindkjølen presented a research that would expose dramatic writing by the Norwegian teacher and author Emilie Zogbaum, originally from Horten in the South of Norway, who was a teacher in Hammerfest. Zogbaum was a friend of Henrik Ibsen, and Ibsen was the one who produced her play Eighteen Years After at Kristiania Norske Teater (The Norwegian Theatre in Kristiania/Oslo) under the pseudonym Thorbjørn Bjelle in 1861. The play was written in the romantic tradition, inspired by the German Theodor Mügge who travelled to Finnmark in the summer of 1840 and wrote a book titled in German Skizzen aus dem Norden (Sketches from the North) on his experiences. According to Lindkjølen, Mügge here describes the Sámi as people yet not caught up by civilisation. Later Mügge concretises this in the novel Afraja (1854) about a "Sámi chief", the daughter of whom falls in love with a Danish merchant and the impossibility of such a 
relationship. ${ }^{9}$ However, in Atten aar efter (Eighteen Years After), Zogbaum does the contrary in her play by the same name, by showing a will for integration or dialogue in-between cultures, like when Afraja is allowed to go with William Steen to Hammerfest, because there is a fortune to be inherited. Afraja is after all "half Norwegian".

Eighteen Years After is a play which has been spoken about as the first Sámi play, in spite of not being written by a Sámi author. The influences of it, and the way clashes of culture between mystical women and rational men is taken on by Zogbaum's friend Henrik Ibsen, can be seen in perspective of such cultural clashes, so to say between nature and culture. In the case of Ibsen's own plays, we speak about female characters like Elida Wangel in The Lady from the Sea (Fruen fra havet, 1888) and Rebecca West in Rosmersholm (1886). Both are fiction-characters originating from the arctic part of Norway, presumably Finnmark, and are of either Kven (Finnish) or Sámi identity. They are marked by strong feelings for nature and the mystical as something un-outspoken or un-heimlich, which creates strong tensions with their Norwegian men ruled by reason and discipline. This is a clash of culture related to the image of the femmes-fatales, which in Ibsen's dramatic production also can be traced in The Vikings at Helgeland (Hormennene på Helgeland, 1858, revised in1893), where Hjørdis is such a strong Viking-woman of the north who creates fatal intrigues. This is an example of cultural clashes being crucial to Henrik Ibsen as a dramatic writer.

Knut Hamsun grew up in the Arctic North, and cultural clashes are supposed to have inspired him throughout his literary career. ${ }^{10}$ And for the Sámi aspect, the "lap" (a vernacular expression for a Sami person) plays a role in Hamsun's authorship, like in the Drama of Life (Livets spill, 1896, in the Kareno Trilogy), the role figure Thy is announcing the coming of the plague from the far North. In his Nobel prize winning novel, Crops of the Earth (Markens grøde, 1917), there is a conflict about who has the right to the soil, the Sami hunters or the Norwegian farmer as coloniser of the earth. So far, cultural clashes can be seen as contained in Arctic Drama of the $19^{\text {th }}$ and early $20^{\text {th }}$ centuries. Similar clashes can be found in the blossoming of Sámi Theatre some decades later.

\section{CULTURAL CLASHES TOWARDS DECOLONISATION}

There was no established tradition for running professional theatre in the Sámi languages, but a certain performativity was to be found in the tradition of the storytelling and the joik, Sámi chanting, and even in a Sámi acrobat. ${ }^{11}$ In his book The Sámi People of the North: A Social and Cultural History, Neil Kent writes: "Although theatre was not a Sámi tradition, in the 1970s performance companies were established and rapidly began to blossom", thus introducing some of the companies and their background, ${ }^{12}$ like Dálvadis in Karesuando, Northern Sweden in 1971 and Beaivvás in Kautokeino, Northern Norway in 1981. This blossoming must be seen in connection with the discovery of a strong regional cultural identity, especially in the 1970s, something that also took place within the Sámi population and supported by non-Sámi cultural workers.

The new Sámi Theatre would establish itself on different sources. One of the people advising the new Sámi Theatre as a dramaturge was the Danish playwright and philosopher Ulla Ryum. She presented her idea of a spiral and circular dramaturgy at drama seminar at Kautokeino in September 1985, at which Ryum was one of the lecturers presenting (Ryum 1986). In an interview with Per Brask from the Drama department at the City University of Winnipeg, Ryum expressed her ideas of strategies for an aboriginal theatre, pointing out that aboriginal people, the so-called Fourth World People, has started to use theatre and urban media to express their self-respect. ${ }^{13}$

The circular or spiral dramaturgy that Ryum prescribed for the indigenous theatre would break away from the classical European dramaturgy based in Aristoteles, and it is defined as a non-Aristotelian storytelling. ${ }^{14,15}$ However, in film, like in the film by Nils Gaup, The Pathfinder (1987), they used a standardised dramaturgical form, based on the Aristotelian tradition. But in theatre Dálvadis Teátter and other Sámi Theatre initiatives showed a willingness to develop a form of hybridity, with elements like 
narrating theatre, rituality and performance art, which also applies for the Beaivvás sámi Teáhter in Kautokeino in some of their productions influenced by elements of Noh-theatre thanks to the Icelandic theatre director Haukur J. Gunnarsson, who was educated in Japan.

In the Dálvadis production 8 Minutes Before the Sun (8 minuter från solen) in Stockholm in 1987, and as I wrote in an article in Nordic Theatre Studies, there was a striking contrast between attachment to a theatre of bodily energies, reminiscent of the Greenlandic Tuukkaq theatre and use of non-acting of a performative which is including elements of the ritual, drum and mask dances. In this sense Dálvadis and Tuukkaq are coinciding.

"/.../From a dramaturgical point of view the basic structure of the action (in 8 Minutes Before the Sun, my remark) was fragmentary, dealing with the relationship between two Sámi girls, vigjhemit in the Sámi language, and the Shaman, noaide, who at the time was acting as the wild animal, the coyote."16

The laboratory theatrical praxis was slightly under the inspiration of Odin Teatret. Tuukkaq was founded in Fjaltring, Denmark in 1975, a striking example of a laboratory theatrical approach focusing on the figurativity of the body, and rediscovering old Greenlandic shamanist traditions such as mask and drum dances. Sámi and Greenlandic were trained with Reidar Nilsson in his laboratory theatre in Fjaltring, as was the case with Àsa Simma, the co-founder of Dálvadis (together with Harriet Nordlund), as well as the American indigenous performance artist Norman Charles. Others who trained with Tuukkaq were Greenlandic actresses Makka Kleist and Elisabeth Heilmann Blind. Kleist was working with Beaivvás and independent companies, and returned to Greenland to work with the The National Theatre of Greenland, which was founded in 2011. ${ }^{17}$ Heilmann Blind would go on working with Samiska teatern in Kiruna, Giron Sámi Teáhter, established as a follower of Dalvádis in 1992. Thus, we can speak about an Inter-Nordic exchange including Greenland.

Beaivvás Sámi Teáhter gained status as Sámi regional theatre from 1990 and obtained status as a national theatre for the Sámi people in the Sápmi region of the North from June 2001, under the name of Beaivvás Sámi Nasunálteáhter. As a touring company it tours in Northern Sweden and Northern Finland, and sometimes performs in the capital cities about postcolonial situations, especially when natural resources like mining are being exploited in a devastating way by the dominant society. This is a conflict of interest between a more ecological use of resources for the benefit of reindeer-herding on one hand, and profit from external exploitation on the other. This conflict came to display in the 8-minutes Before the Sun production by Dalvádis, as well as in Deáarvvuodat (Greetings), a production by Beaivvás Sámi Teáhter from 1993, which dealt with the question of suicide related to this cultural clash, which in the play resulted in a suicide by a young boy. Deáarvvuodat, was directed by Anitta Suikkari in a co-operation with Mary Sarre who as sole actor presented a monologue about the suicide. Sarre portrayed a mother who tries to understand why her son committed suicide. So, the production simultaneously dealing with the conflict between modern urban society and the more nature-based, which is in did both a cultural and a memorial conflict. By the scenography, it was based on the form of a sledge to be pulled by reindeer. ${ }^{18}$ The topic of suicide among indigenous people due to conflicts about life forms is a tension, which was one of the main themes in much artistic production of indigenous people during the 1980s and 1990s. Many means of expressions from artistic hybridisation were used to touch upon it in a spiral dramaturgical way, which certainly can be seen in the perspective of the nomadic lifestyle of following herds from pasture to pasture.

\section{THE DIALOGIC SPACE OF SHARED CULTURE: INTERACTION IN-BETWEEN CENTRE AND PERIPHERY}

Little by little an exchange with Sámi and Norwegian, Swedish or Finnish theatre would come about, indicating dialogic interaction in a shared cultural space. Hålogaland Teater established in 1971 in Tromsø, is a Norwegian regional institutional theatre for the northern part of Norway on touring basis. Brechtian inspiration was strong at hand in the beginning, as well as willingness to perform in North-Norwegian dialects. It was the first 
professional institutional theatre north of the polar circle, with the obligation of touring in the arctic part of Norway. In co-operation as well with the smaller companies of Sampo Teater and the Studioteateret of Trondheim, they joined up with Beaivvás Sámi Teáhter in the production of Bertolt Brecht's The Good Man from Sezuan in 1991, an outdoor ice-theatre production directed by Dutch stage director Jos Gronier. This production won the prize of the best Norwegian production of that year and was later shown in Tromsø at the shores of a small lake at the top of the Tromsø Island (video stills, Norwegian Broadcasting Corporation). This production was characterised by intercultural exploration in theatre work in which people of many nationalities and from many theatre groups participated as actors. The production reflected a dynamic, which in an Arctic perspective may be viewed as the beginning of a new wave characterised by the intercultural and international connection to a Northern and Arctic identity. There was a strong vernacular touch in this production, and the use of Sámi language became a political statement. Icelandic stage director Haukur J. Gunnarsson was an artistic director in Beaivvàs Sámi Teàhter for two periods, from 1991 to 1996 and in a new period from 2007 until 2019. Gunnarsson has been very preoccupied with traditional Japanese theatre forms like Noh theatre, something that was expressed throughout the production of Narukami by Beaivvàs in 1992, which was a dramatising of an old Japanese tale. Thus, we see a shared culture in a dialogic space also on global basis.

Further example of an interaction reflecting a dialogic space in Scandinavian drama, although not written by a Sámi playwright, is to be found in the drama The Kayak Woman (Kajakkkvinnen) by Swedish dramatist Per Verner-Carlsson, a play which was staged by Beaivvàs Sámi Nasunàlteàhteas in 2003, as a co-production independent company Sampo, and directed by Finnish-Sámi actress Anitta Suikkari. At this time Harriet Nordlund was a dramaturg of this production, and she reworked Verner-Carlsson's play about communication across cultural and linguistic barriers with a touch of gender and ecology, and indeed reflecting the topographic point of non-orientable surfaces in the sense of non-orientability in surfaces like arctic or ice deserts, where there are hidden signs in the landscape to help you find the way. ${ }^{19}$

The play had first been staged at Dramaten (The Royal Dramatic Theatre) in Stockholm 1982, and is about a woman about to separate from her husband due to quarrel of linguistic understanding. The action moves symbolically from ice flake to ice flake, and we experience the mythological level of the play, almost as a metaphor of a non-logical or non-linear search for identity. It was a focus on linguistic-philosophical perceptions of how a kayak may be described in relation to how it really is looking seen from different point of view, the male or the female view reflecting a symmetric vs. a nonorientable topology. This becomes crucial in how the female main character understands herself when the husband insists that it is a canoe, so the kayak becomes an icon picked up from arctic areas viewed in relation to nomadic life forms which are of a non-orientable kind. This female point of view is opposed to the male-view, insisting that a kayak is a canoe. However, the woman intuitively knows how a kayak looks.

\section{ASPECTS OF CULTURAL EXCHANGE IN SHARED DIALOGIC SPACES}

In the 1980s the topic of nomadism vs. industrialisation and urbanisation was very urgent to indigenous societies, whether it was in Northern Scandinavia or in Arctic Canada. It was a time when indigenous culture was at stake, but now much has changed. A Sámi coastal theatre representing the Sámi agricultural and fishing village identity, came to expression in Totalteatret from Tromsø, questioning the more oppressed Sámi identity in the coastal areas of Northern Norway where nomadism was not at hand any more. The festival Riddu Riddu Festivála in Kåfjord was based in such perspectives as the costal and the nomadic, and developed into an international festival for indigenous music and cultural shows.

When Umeå in Northern Sweden was Cultural capital of Europe in 2014, there was an opening event which in one way closes the conflict between centre and periphery, but in another way opens a new: The touristic trap. In Umeå the opening event was a Sámi co-operation with Künstlergruppe Phase 7 from 
Berlin, and Berliner Zeitung (5.2. 2014) wrote in a review that:

"/.../On the frozen river the Berlin based artist Collective Phase 7 , under the artistic direction of the media artist Sven Sören Beyer had raised a couple of Sámi tents and five stages and thus created a high-tech framework of light and sound effects ... Then the famous joik is starting. The female singers Inga Juuso and Ulla Pirttijärvi sang out songs with a strong force, that the techno ambience and the lighting effects were even more effective," ${ }^{20}$ (my translation from German).

This production was shown on German television, and thus we see how Sámi and indigenous culture is being exposed to globalisation and global community, with regard to tourism and the danger of exotism, like the case has been in Greenland with touristic interest in mask and drum dancing. And it shows how unavoidable it is with regard to becoming a part of a much wider community of theatrical culture and performance. However, due to the demand for sustainability and the climate change, the closeness to nature will be dominating and opening up for more international cooperation in Arctic Drama and Sámi Theatre and other indigenous performance. Sámi and indigenous cultures and their cultural clashes have by the venue of Sámi Theatre come to decolonise situation in the sense of entering into the dialogic space of shared culture. Arctic Drama and Sámi Theatre, then, can be spoken about as happening in new shared dialogic spaces. Decolonialisation has contributed to creating new spaces for new theatre and drama in spite of the historical cultural appropriation, towards the recognition of equality of voices in the blossoming of theatre that took place in the Sápmi, and which also has happened in Greenland in the aftermath of Tuukkaq, like is actually being researched in by a group of Danish, Norwegian and Greenlandic researchers. ${ }^{21}$ This publication gives some examples of Greenlandic theatre and shows how to research a theatre history in-between historical amateur theatre and the final establishment of a Greenlandic National Theatre in 2011. This study will hopefully soon be available in English, but so far, I have to conclude with the fact that in a Norwegian and Northern Scandinavian context, dialogic spaces and shared culture has contributed to the decolonising project and created a meeting point for centre and periphery.

\section{References}

Arntzen, Knut Ove. "Hybrid and Cultural Identity - After the Mainstream. Arctic Theatre from Scandinavia in a Post-Mainstream Perspective". Nordic Theatre Studies, Vol. 7, ed. Kacke Götrick, Gideå: Föreningen Nordiska Teaterforskare, 70 (1995): 72-74.

- Arctic conditions for the Arts: Landscape of Non-Orientable Surfaces - Ecology and Gender, TRANS Internet journal for cultural studies. Vienna, INST, Nr. 20. Last downloaded March $7^{\text {th }} 2021$. https://www.inst.at/trans/20/arctic-conditionsfor-the-arts-landscape-of-non-orientable-surfaceecology-and-gender/.

. "Alongside Struve's meridian arc: Symbolic reflection of memories". Meno istorija ir kritika/Art History \& Criticism 6. Kaunas: Vytautas Magnus University, 2010. Last downloaded 7 March 2021. Web. ref.: https://www.vdu.lt/cris/handle/20.500.12259/32085.

This article has later been published in a revised version: "A Metaphorical View on Cultural Dialogues: Struve's Meridian Arc and Reflections on Memories in Eastern and Northern Borderlands". In eds. Helge Vidar Holm, Sissel Lægreid and Torgeir Skorgen, The Borders of Europe. Hegemony, Aesthetics and Border Poetics, 127-136. Aarhus: Aarhus University Press, 2012.

. "Scenic Landscapes and Dialogic Spaces on the Outskirt of Europe: Arctic Drama and Polar Surrealism in the Arts - A Cross-disciplinary Approach". Europe and Its Interior Other(s), eds. Helge Vidar Holm, Sissel Lægreid and Torgeir Skorgen, Aarhus: Aarhus University Press, 2014, 185-199.

- "Perspectives nomades et 'spiraldramaturgi"'. Ed. Francoise Quillet. CIRRAS: La Scène mondiale aujourd'hui. Des forms en movement. Paris: L'Harmattan, 2015, 513-529, 514.

- "Tuukkaq, Silamiut og Grønlands Nationalteater. Antropologisk vending til ny-kontekstualiserte klassiskere - mytedramaturgi og inter-nordisk utveksling". Grønlands Teaterhistorie - på vej, special volume, Peripeti, tidsskrift for dramaturgiske studier, eds. Susanne Andreasen, Knut Ove Arntzen, Annelis Kuhlmann, Birgit Kleist Pedersen, Aarhus: Aarhus University, 2019, 38-53.

Brask, Per. "Performance in the Fourth World: An Interview with Ulla Ryum". In Aboriginal Voices. Amerindian, Inuit and Sami Theater, eds. Per Brask and William Morgan, Baltimore and London: The Johns Hopkins University Press, 1992.

Buttry, Dolores. "SEIN and WOLLEN: 'Drama' as Hamsun's inspiration”. International Association of Scandinavia Studies, IASS_abstract_book 1 pdf for 27. IASS-conference, Nordic Drama: Renewal and transgression, 4-9.08. 2008, Gdansk: University of Gdansk, 2008, 40-41.

Brynhildsvold, Knut. "Sultens scenografi. Om teatraliteten i Knut Hamsuns 'Sult". International Association 
of Scandinavian Studies, IASS_abstract_book 1 pdf for 27. IASS-conference, Nordic Drama: Renewal and transgression, 4-9.08. 2008, Gdansk: University of Gdansk, 2008, 37.

Fjågesund, Peter. The Dream of the North. A Cultural History to 1920. Amsterdam - New York: Rodopi, 2014.

Jähner, Harald. "Wolfsheulen und Kunstgruppen”. In Berliner Zeitung. Daily Newspaper, Berlin, Germany, 5.2. 2014.

Kent, Neil. The Sámi People of the North. A Social and Cultural History. London: Hurst and Company, 2018, 192.

Oskal, Sara Margrethe. Skealbma ut $i$ verden- samisk gjøglertradisjon i fortellinger og joik, og moderne sceneutrykk. PhD, KHIO-Oslo National Academy of the Arts, 2009.

Lindkjølen, Hans. "Arktisk teater og drama. Fra Theodor Mügge til Henrik Ibsen. Nordlandsromantikk - et litterært tema”. International Association of Scandinavia Studies, IASS_abstract_book 1 pdf for 27. IASS-conference: Nordic Drama, Renewal and transgression, 4-9.08. 2008, Gdansk: University of Gdansk, 2008, 79-81.

Ryum, Ulla. Om den ikke-aristoteliske fortaelleteknik. Rapport från seminariet "Dramatikern i dialog med sin samtid”. II delen, 4-11.6. 1982 Reykjavik: Nordiska Teaterkommiteen, 2. printing, Oslo: Nordiska Teaterkommiteen, Oslo, 1986.

Schuler, David. "East meets west: Joik-driven dramaturgy and Noh theatre in the Beaivvás Sámi Teáhter's production of "The Frost-Haired and the Dream-Seer". International Association of Scandinavia Studies, IASS_abstract book 1 pdf for 27. IASS-conferene, Nordic Drama: Renewal and transgression, 4-9.08. 2008, Gdansk: University of Gdansk, Gdansk 2008, 104-105.

Weinstein, Arnold. Northern Arts. The Breakthough of Scandinavian Literature and Art, from Ibsen to Bergman. Princeton and Oxford: Princeton University Press, 2008.

\section{Notes}

1 Knut Ove Arntzen, "Alongside Struve's meridian arc: Symbolic reflection of memories", Meno istorija ir kritika/ Art History \& Criticism 6 (Kaunas: Vytautas Magnus University, 2010). This article has later been published in a revised version: "A Metaphorical View on Cultural Dialogues: Struve's Meridian Arc and Reflections on Memories in Eastern and Northern Borderlands". In The Borders of Europe. Hegemony, Aesthetics and Border Poetics, 127136, eds. Helge Vidar Holm, Sissel Lægreid and Torgeir Skorgen (Aarhus: Aarhus University Press, 2012).

2 Knut Ove Arntzen, "Scenic Landscapes and Dialogic Spaces on the Outskirt of Europe: Arctic Drama and Polar Surrealism in the Arts - A Cross-disciplinary Approach", Europe and Its Interior Other(s), eds. Helge Vidar Holm, Sissel Lægreid and Torgeir Skorgen (Aarhus: Aarhus University Press, 2014), 185-199.

3 Arnold Weinstein, Northern Arts. The Breakthrough of Scandinavian Literature and Art, from Ibsen to Bergman (Princeton and Oxford: Princeton University Press, 2008).
4 Peter Fjågesund, The Dream of the North. A Cultural History to 1920 (Amsterdam - New York: Rodopi, 2014).

5 Knut Ove Arntzen, "Perspectives nomades et 'spiraldramaturgi”, CIRRAS: La Scène mondiale aujourd'hui. Des forms en movement, ed. Francoise Quillet (Paris: L'Harmattan, 2015), 513-529, 514.

6 David Schuler, "East meets west: Joik-driven dramaturgy and Noh theatre in the Beaivvás Sámi Teáhter's production of 'The Frost-Haired and the Dream-Seer", International Association of Scandinavian Studies, IASS_abstract book 1 pdf for 27. IASS-conference, Nordic Drama: Renewal and Transgression, 4-9.08. 2008 (Gdansk: University of Gdansk, Gdansk 2008), 104-105.

7 Sara Margrethe Oskal, Skealbma ut i verden- samisk gjøglertradisjon $i$ fortellinger og joik, og moderne sceneuttrykk ( $\mathrm{PhD}$, KHIO-Oslo National Academy of the Arts, 2009).

8 Knut Brynhildsvold, "Sultens scenografi. Om teatraliteten i Knut Hamsuns 'Sult", International Association of Scandinavian Studies, IASS_abstract_book 1 pdf for 27 . IASS-conference, Nordic Drama: Renewal and Transgression, 4-9.08. 2008 (Gdansk: University of Gdansk, 2008), 37.

9 Hans Lindkjølen, "Arktisk teater og drama. Fra Theodor Mügge til Henrik Ibsen. Nordlandsromantikk - et litterært tema", International Association of Scandinavia Studies, IASS_abstract_book 1 pdf for 27. IASS-conference: Nordic Drama, Renewal and transgression, 4-9.08. 2008 (Gdansk: University of Gdansk, 2008), 79-81.

10 Buttry, Dolores, "SEIN and WOLLEN: 'Drama' as Hamsun's inspiration", International Association of Scandinavian Studies, IASS_abstract_book 1 pdf for 27 . IASS-conference, Nordic Drama: Renewal and Transgression, 4-9.08. 2008 (Gdansk: University of Gdansk, 2008), $40-41$.

11 Sara Margrethe Oskal (2009, ibid.).

12 Neil Kent, The Sámi People of the North. A Social and Cultural History (London: Hurst and Company, 2018), 192.

13 Per Brask, "Performance in the Fourth World: An Interview with Ulla Ryum", in Aboriginal Voices. Amerindian, Inuit and Sami Theater, eds. Per Brask and William Morgan (Baltimore and London: The Johns Hopkins University Press, 1992).

14 Ulla Ryum, Om den ikke-aristoteliske fortaelleteknik. Rapport från seminariet "Dramatikern i dialog med sin samtid", II delen, 4-11.6.1982 Reykjavik: Nordiska Teaterkommiteen, 2. printing (Oslo: Nordiska Teaterkommiteen, Oslo, 1986).

15 Sara Margrethe Oskal (2009, ibid.).

16 Knut Ove Arntzen, "Hybrid and Cultural Identity After the Mainstream. Arctic Theatre from Scandinavia in a Post-Mainstream Perspective", Nordic Theatre Studies, Vol. 7, ed. Kacke Götrick, (Gideå: Föreningen Nordiska Teaterforskare, 1995), 70.

17 Knut Ove Arntzen, "Tuukkaq, Silamiut og Grønlands Nationalteater. Antropologisk vending til ny-kontekstualiserte klassiskere - mytedramaturgi og inter-nordisk utveksling", Grønlands Teaterhistorie - på vej, special volume, Peripeti, tidsskrift for dramaturgiske studier, eds. Susanne Andreasen, Knut Ove Arntzen, Annelis Kuhlmann, Birgit Kleist Pedersen (Aarhus: Aarhus University, 2019), 38-53.

18 Knut Ove Arntzen (1995, ibid.), 72-74.

19 Arntzen, Knut Ove, Arctic conditions for the Arts: Landscape of Non-Orientable Surfaces - Ecology and 
Gender, TRANS Internet journal for cultural studies (Vienna, INST, Nr. 20), web.ref.

20 Harald Jähner, Harald, "Wolfsheulen und Kunstgruppen", in the Berliner Zeitung (Daily Newspaper, Berlin, Germany), 5.2.2014.
21 Grønlands Teaterhistorie - på vej, special volume, Peripeti, tidsskrift for dramaturgiske studier, eds. Susanne Andreasen, Knut Ove Arntzen, Annelis Kuhlmann, Birgit Kleist Pedersen (Aarhus: Aarhus University, 2019), 38-53. Title of volume in English: The Theatre History of Greenland - in process.

Knut Ove ARNTZEN

Bergeno universitetas, Norvegija

\section{ARKTINĖ DRAMA SÁMIŲ TEATRE - DEKOLONIALIZMO KULTŪRINĖS TRINTYS DIALOGINĖSE DALIJIMOSI ERDVĖSE}

\section{Santrauka}

Straipsnyje nagrinèjamas arktinès dramos (Arctic Drama) konceptas - santykis tarp dramos ir kultūrinių trinčiu dalijimosi kultūros kontekste. Šis konceptas būdingas Šiaurès Skandinavijos regionui ir apibrěžiamas Arkties sąvoka geografine prasme. Šiame tuščiame regione sámių tauta istoriškai iki šių dienų gyvena gamtai artimą klajoklių gyvenimo būdą, ganydami elnius. Istoriškai norvegai ir švedai kolonizavo ši kraštą ir ypač žvejybai naudojamus krantus. Nuo vikingų laikų čia susiklostè stiprios kultūrinès trintys, bet kolonizacija iš esmès prasidèjo gerokai vèliau, per jègą siūlydama krikščionybę XVI amžiuje. Šios etnokultūrinès trintys Romantizmo epochoje pradèjo atsispindèti dramoje ir teatre, dalyje Henriko Ibseno ir Knuto Hamsuno pjesių. Nepriklausomas sámių tautos teatras, panašiai kaip ir Grenlandijos ir Kanados inuitų bei vietinių gyventojų teatrai, išvysto strategijas, apibūdinams kaip „spiralinè dramaturgija“. Kultūrinè nepriklausomybe prisidèjo prie dekolonizacijos proceso, išryškinančio kultūrines trintis teatre ir dramoje, apibūdinamas kaip postkolonializmas akistatoje su kolonializmu. Šiame straipsnyje nagrinejjama arktinè Skandinavija.

Reikšminiai žodžiai: arktinè drama, sámiai ir vietiniai gyventojai, dialoginès erdvès, dalijimosi kultūra, centras ir periferija.

\section{Knut Ove ARNTZEN}

Knut Ove Arntzen born 1950, professor of theatre studies at the Department of Linguistic, Literary and Aesthetic Studies at the University of Bergen, Norway, and since November 2020 retired in the position of professor emeritus. Arntzen has also been working as a freelance theatre critic and scientific consultant to festivals in Bergen and Montreal, and a visiting professor to different universities, like in Kaunas (Lithuania), Antwerp (Belgium) and Frankfurt am Main (Germany). International conferences among others: Glasgow, Amsterdam, Copenhagen; has published a series of articles analyzing development in the scope of a visual kind of dramaturgy and post-mainstream, cooperated in seminars at the Eurokaz festival with Gordana Vnuk; 1997 and 1998 attended conferences about new theatre and theatre research (Frankfurt, D; PueblaCholula, Mexico; Johannesburg, South Africa; Canterbury, UK). Later conference participation: Humanioria and science at the Université de Yaoundé I, Cameroon in March 2016, and ANTS (Association of Nordic

Theatre Studies), in Århus and Kaunas, 2017. In 2020 publication of the book Staging and Recycling. Retrieving, Reflecting and Re-framing the Archive, co-written and co-edited by John Keefe, London: Routledge. E-mail: knut.arntzen@uib.no 